\section{INTRODUCCIÓN \\ SOBRE EL ORIGEN, EVOLUCIÓN, LIIMITES Y OTROS DEBATES TEÓRICOS EN TORNO A LA HISTORIETA}

Antonio Altarriba

Universidad del País Vasco

\section{INTRODUCTION TO THE ORIGINS, THE EVOLUTION, THE LIMITS AND OTHER THEORETICAL DEBATES AROUND THE CARTOON STORIES}

La historieta constituye un objeto de estudio singular, en cierta medida caso único, por el escaso interés que hasta épocas recientes ha suscitado. Debido, quizá, al tono satírico y al sesgo caricatural que cultivó en el siglo XIX 0 al carácter infantil, a menudo moralizante, que revistió en el $X X, 0$ a la popularidad - no exenta de vulgaridad- que alcanzó entre 1930 y 1960, ha quedado relegada por todas las disciplinas. Y ello a pesar de participar de muchas, pues guarda relación con la literatura, el dibujo, la pintura, el grabado, el periodismo y el cine, incluso, si bien se mira, con el teatro, el diseño o la arquitectura. Tan prestigiosa familia no la ha librado -más bien ha propiciado-su prolongada orfandad conceptual. Solo en los años sesenta del siglo pasado se inicia en Europa un movimiento de reivindicación, recuperación y primera catalogación de un patrimonio que se descubre vastísimo y, sobre todo, influyente, pues configura el imaginario de varias generaciones de niños y adolescentes. Independientemente de su cuestionada calidad, al menos ofrece cantidad. Así pues, el carácter masivo de su difusión justificó, condicionó y, de alguna manera, todavía condiciona el estudio de la historieta.

En estos cincuenta años de esporádica tradición teórica se ha avanzado lo suficiente para comprobar que el objeto de estudio es más complejo de lo que sus populares avatares permiten suponer. De hecho, el desconocimiento de algunas de sus claves, hasta de sus propios ingredientes constitutivos, motiva encendidos debates, propicia la discrepancia, a veces el sectarismo, y dificulta el asentamiento de modelos de análisis. Muchos "especialistas" seguimos sin saber qué es, cómo funciona, ni siquiera dónde empieza o dónde termina. ¿Qué diferencia la historieta de un relato literario generosamente ilustrado? ¿Pueden considerarse historietas las viñetas de humor gráfico que aparecen en la prensa? ¿Y un mural compuesto por una secuencia de imágenes? ¿Y una colección de tapices que desarrolla un tema o cuenta una historia? ¿Y el retablo de una iglesia que escenifica la vida de un santo? ¿Y las muy narrativas iluminaciones de un códice medieval? ¿Y las inscripciones prehistóricas de una cueva...? De hecho, se mantiene desde décadas una discusión, con importantes desacuerdos, acerca de sus orígenes. Aunque no solo su cronología se presta al disenso. Abundan quienes se refieren a la historieta como un "género", incluso como un "subgénero". Suelen provenir del ámbito filológico y, sin duda, pretenden encajarla como un apartado más de la literatura, quizá entre el teatro y la narrativa 0 entre la comedia y la picaresca 0, peor, entre la novela policíaca, la ciencia ficción y cualquier otra forma narrativa de gran consumo.

Lo primero que hay que afirmar al respecto es que nos encontramos ante una forma de expresión específica, un medio de comunicación perfectamente diferenciado, como el cine, la pintura o la literatura. Dentro de él existen -al igual que en el cine, la pintura o la literatura- géneros, subgéneros, registros, tonos, estilos... Y así tenemos historietas de humor, eróticas, sentimentales, de aventuras, de terror, de fantasía... Pero también poéticas, históricas, filosóficas, periodísticas, biográficas, autobiográficas, experimentales 0 , simplemente, inclasificables. Todas ellas están contadas siguiendo un código, una gramática pictográfica, una retórica escripto-icónica, un combinado léxico-gráfico, que las dota de originalidad al tiempo que las hace legibles. Utilizados e implicados de muy diversas maneras, estos elementos constitutivos de su lenguaje son, como venimos diciendo, motivo de discordia y confusión. La mixtura de palabra e imagen que parece presidir su origen se combina en proporciones variadas, cada una cargada de 
matices y, además, declinable en función de obras 0 autores. El "sistema" de la historieta se halla lejos de ser repertoriado. Más aun de estar conceptualmente consensuado.

La imprecisión teórica conlleva la histórica. Si no sabemos qué es, difícilmente podremos determinar cuándo empieza 0 cómo evoluciona. Y no cabe duda de que estamos todavía lejos de conocer su esencia o de establecer la rigidez o la elasticidad de sus límites. Porque ni siquiera una definición simple de historieta como "relato en imágenes dibujadas" queda exenta de objeciones. ¿Y si las imágenes no están dibujadas sino esculpidas en piedra, grabadas en madera, bordadas en tela, inscritas en cerámica, forjadas en hierro, recortadas en cristal, pintadas en lienzo...? La lista de grandes narraciones contadas en bajorrelieves, vidrieras, crateras, murales, series de tapices o cuadros es abundante, rica en cualidades plásticas y en logros expresivos. Sin embargo, salvo excepciones, no suele ser tenida en cuenta. De manera paradójica para un medio en busca de reconocimiento artístico, los estudiosos de la historieta han acotado su campo con criterios restrictivos, dejando fuera obras que, independientemente del prestigio que puedan aportar, enriquecerían el medio, al menos ayudarían a entenderlo.

La mejor prueba del carácter restrictivo de estos criterios la aporta el origen que, todavía mayoritariamente, se suele dar a la historieta. No basta con que sea un relato en imágenes "dibujadas". Tiene que ser reproducido de forma impresa. Debe organizarse secuencialmente en espacios figurativos contiguos dentro de un espacio global (viñetas en una página). El texto tiene que venir incorporado de manera autógrafa dentro de la viñeta. Los diálogos deben presentarse en bocadillos, la narración resultar autosuficiente, el "raccord" entre viñetas ofrecer unas comprensibles relaciones de causalidad... Y aun hay quienes añaden condiciones complementarias como la difusión masiva o el protagonista fijo en las diferentes entregas. Todo este entramado de requisitos lleva a la hipótesis -injusta más que absurda - de que la historieta nació el 25 de octubre de 1896 cuando el dibujante Richard Felton Outcault puso a su personaje Yellow Kid a hablar en bocadillos en las páginas de un periódico norteamericano, New York Journal. Y ello -véase el ejemplo "The Yellow Kid and his New Phonograph"-a imitación de un fonógrafo que, en realidad y como gag final, escondía un loro.

El establecimiento de una fecha tan precisa y de un recurso tan concreto como acto fundador se hace aún más discutible cuando descubrimos que un grupo de once "expertos" (Claudio Bertieri, Javier Coma, Álvaro de Moya, Luis Gasca, Denis Gifford, Vasco Granja, Maurice Horn, Richard M arschall, Claude Moliterni, David Pascal y Rinaldo Traini) rubricaron esta partida de nacimiento. Lo hicieron el 30 de octubre de 1989 en el marco del Festival de Lucca. El documento, redactado y firmado como si de un acta notarial se tratara, parece querer imponer su dictamen por el principio de autoridad y, sobre todo, dar el pistoletazo de salida para la celebración de un eventual centenario que, al final, resultó menos festejado y menos rentable, tanto económica como culturalmente, de lo que se pretendía.

De hecho, desde entonces los derroteros historiográficos de la historieta se han ido relativizando y también han ido retrasando la fecha de su posible nacimiento. En 1994, Thierry Groensteen y Benoît Peeters en L'invention de la bande dessinée, aun teniendo en cuenta antecedentes y consecuentes, otorgan un papel fundacional a la figura del suizo Rodolphe Töpffer y sitúan el invento en torno a 1830. En 2009, Thierry Smolderen en Naissances de la bande dessinée -obsérvese el plural "nacimientos"- parte de William Hogarth para hacer su recorrido historietístico, que arranca así de 1732. Y la revisión de los orígenes no se detiene ahí. En los últimos años la obra del estudioso norteamericano David Kunzle está convirtiéndose en referencia cada vez más aceptada. Y en el primer volumen de su The History of the Comic Strip, publicado ya en 1973, establece 1450 como punto de partida de la narrativa gráfica.

A pesar de las diferencias cronológicas y conceptuales que separan estos puntos de vista, sorprenden ciertas similitudes argumentativas. Todas las hipótesis encuentran fundamento en un contexto social, cultural 0 , simplemente, técnico más amplio. Como si la historieta no tuviera su propio cauce evolutivo, como si careciera de una dinámica propia que explicara sus diferentes manifestaciones, los mencionados teóricos cuelgan, al menos apoyan, el origen del medio en acontecimientos de mayor envergadura o históricamente más estructurantes. Así, 1896 correspondería al momento culminante del "melting pot", la caldera étnica de la que va a surgir la potencia dominante del siglo XX. La historieta cobra, desde esta perspectiva, una dimensión eminentemente norteamericana y contribuye a cohesionar, con sus historias sencillas y visuales, una población de origen y lenguas diversas. Töpffer y 1830 colocan el invento 
en la confluencia con el de la fotografía, en la crisis de la representación figurativa en pintura y, más genéricamente, al amparo de la revolución industrial. Hogarth en 1732 se encuentra bajo el impulso de una ascendente clase burguesa y del muy crítico espíritu de la llustración. ¿Y qué decir de 1450, la fecha propuesta por Kunzle? No solo es el arranque de la modernidad en Europa sino el inicio de la imprenta.

La línea abierta por Gérard Blanchard en su Histoire de la bande dessinée (1969) sigue, de momento, inexplorada. Aunque las nuevas tendencias críticas la convierten en opción cada vez más tentadora. Como ya sugiere el subtítulo (Une histoire des histoires en images de la préhistoire à nos jours, "Una historia de las historias en imágenes desde la prehistoria hasta nuestros días"), el periodo cronológico contemplado aumenta considerablemente. Con las diferencias temáticas y materiales propias de cada época, Blanchard sigue un hilo continuo que le lleva desde las pinturas rupestres hasta la actualidad. De hecho, la cronología con la que se cierra el libro arranca hacia el 30.000 a.C. y termina en 1968 con La Saga de Xam de Nicolas Devil.

La anexión de una buena parte de las artes plásticas al ámbito de la historieta - parece menos disparatado si hablamos de "narración figurativa", "pictografía narrativa", "relatos iconográficos"...- plantea numerosos problemas. No solo implica una colisión de "estatus" entre obras y formas de análisis -la columna de Trajano/Asterix, la tapicería de Bayeux/Príncipe Valiente, Boticelli/Hergé, Goya/Milton Caniff...-. También la adquisición de las competencias necesarias para un estudio riguroso de tan inabarcable campo. Los teóricos de la historieta deberían añadir la arqueología, la epigrafía, la iconografía, la emblemática, la estética, la historia del arte a sus ya abundantes saberes -semiología, sociología, historia, comunicación y medios...-. Y en el otro sentido - desde la historia del arte hacia el cómic- el trayecto se antoja igualmente complicado. La actual constitución de campos culturales, incluso las áreas de conocimiento tal y como vienen clasificadas por la UNESCO no dan cabida a una disciplina que estudie "el relato en imágenes" en toda su variedad. A pesar de su abundancia y de su persistencia a lo largo de la historia, cualquier acercamiento se antoja parcial, fragmentario, de alguna manera viciado, al menos mutilado, y, por supuesto, sin encaje en una perspectiva global.
Sin embargo, la interdisciplinariedad y la constante ampliación del horizonte investigador no han supuesto obstáculo para otras formas de expresión. La literatura abraza amorosa y armoniosamente la épica, la lírica, la narrativa, la dramaturgia, pero, además o dentro de ellas, el libelo, la intriga policíaca, la poesía amorosa, el ensayo... Y todo ello -y mucho más- servido en la salsa de la sátira, la ironía, el esperpento... Por si fuera poco, cada vez son más los críticos que se interesan por ese "tercer sector" en el que se agruparían refranes, chistes, pintadas, epitafios... Poco les importa si esta extraordinaria diversidad de "textos" se presenta de forma escrita u oral, manuscrita o impresa, sobre pergamino o sobre papel, en rollo, en libro 0 en pantalla, si se vende masivamente 0 se distribuye de forma confidencial... Soporte, formato, técnica de reproducción, tiradas son cuestiones secundarias para el teórico de la Literatura. La palabra en todas sus utilizaciones creativas constituye su objeto de estudio y, en último término, apenas importa que esté publicada o no. El manuscrito perdido, el paquete de cuartillas condenado al cajón, el cuaderno de notas inédito forman parte de la casuística -un tanto mítica, eso sí- del quehacer literario. De manera hipotética pero profundamente arraigada, todos sabemos que algunas de las obras maestras de la narrativa o de la lírica nunca vieron la luz. ¿Se le ocurriría a algún teórico negar carácter literario a la resma de cuartillas recién descubierta en un archivo, una maleta, un contenedor de basura 0 en cualquier otro improbable lugar?

Pues bien, casi ningún historietista vacilará a la hora de afirmar que unos originales inéditos no constituyen un cómic. No, si no están publicados y debidamente difundidos. Los avatares de la reproducción cuentan aquí tanto o más que los de la producción. De hecho, casi todos los historiadores de la historieta toman en cuenta sus diferentes variantes impresas para otorgarle -0 negarle- carta de nacimiento. La imprenta en el caso de Kunzle, la serie de grabados con Hogarth, el álbum con Töpffer, la prensa diaria con Outcault... El proceso de estampación parece importar más que el hecho, evidente y en principio más decisivamente definitorio, de que se trate de un relato en imágenes. Y esta fijación en la mecánica reproductora revela la profunda contradicción de la crítica historietística. Reivindica la condición artística al tiempo que necesita su carácter industrial -las peripecias técnicas de su reproductibilidad- para reconocerla. 
Un original -en papel, en pantalla 0 en otra superficiecompartimentado en viñetas dibujadas es ya una historieta. Los ojos del lector le darán sentido en función de las circunstancias de la recepción, pero su esencia historietística está inscrita desde el momento de la creación. Porque, por mucho que algunos lo reivindiquen, aquí el medio -menos aún la técnica de impresión - no es el mensaje. Y, si no necesita audiencia masiva -la mayor parte de los títulos se mantienen en tiradas reducidas-, ni siquiera reproducción impresa el campo de estudio se abre enriquecedoramente. En último término, todo depende del acuerdo al que lleguemos los desorientados, al menos divididos, "expertos". Independientemente de materiales, soportes y cantidad de difusión, una historia en imágenes siempre vendrá constituida por una figuración reconocible en su identidad y en su expresividad que evoluciona según un proceso secuenciado en uno o varios espacios. Esa es su esencia. Ahí se fragua su capacidad comunicativa. Es todo lo que necesita para que la narración fluya por trazos, formas y colores.

Y no hay que asustarse por la ingente, bulliciosa $-\mathrm{y}$ también selecta- parentela que, con semejante apertura de criterio, nos viene encima. Es más, al hilo de esta reivindicación de la saga visual en su sentido más amplio, podríamos asegurar que en el principio no fue el Verbo. Las primeras representaciones del mundo se construyeron a partir de un impulso mimético y pretendían imitar, de manera realista y progresivamente esquemática, los diferentes aspectos del mundo. En el principio, por lo tanto, fue el icono, quizá en aquellos remotos tiempos percibido como ídolo. Nuestra voluntad inscriptiva cuajó primero en imágenes. Es más, la escritura obedeció a este mismo planteamiento mimético y se presentó cuneiforme, jeroglífica, ideogramática, en cualquier caso figurada. Los fenicios, una civilización más comercial que agrícola, fueron los primeros en inventar un alfabeto fonético. Desde entonces la escritura representa los sonidos de la palabra en lugar del aspecto de la cosa. Ingresamos así en una cultura logocéntrica que nos ha hecho olvidar la primacía icónica. Pero contar historias en imágenes ha sido la primera y principal manera de dejar constancia de nuestra experiencia o de nuestros deseos, en cualquier caso de ese indicio básico de humanidad que es nuestra capacidad de representación simbólica.

Es cierto que una apertura tan amplia de criterios coloca a la historieta en una posición metodológica un tanto incómoda. Desde esta perspectiva toda figuración, desde los cuadros de tema religioso, mitológico o histórico hasta los retratos, contiene un mayor o menor grado de narratividad. Resulta evidente en la figuración que escenifica un acontecimiento. Desarrollando un guión culturalmente implícito para el público al que va destinado y, por lo tanto, perfectamente legible, lienzo, tapiz, grupo escultórico, bajorrelieve construyen las figuras de manera que, por rasgos, atributos o gestualidad resulten identificables tanto en lo que son como en lo que hacen. Y el conjunto se organiza de acuerdo con una secuencialidad interna que permite adivinar las fases del evento escenificado. Por disposición de las imágenes, por su expresividad, hasta por su cromatismo se crea la condensación temporal necesaria para que el episodio quede perfectamente narrado. Incluso la figuración más sobria y estática cuenta un carácter, una textura 0 , como ocurre con las naturalezas muertas, el lento e insoslayable paso del tiempo. Reconozcamos pues que la mayor parte de nuestra plástica tiene alma de viñeta. Y a la recíproca, que el dibujante de cómic hereda de la pintura, la escultura, el grabado una serie de recursos identificativos-expresivos-compositivos que dotan a su trabajo de la imprescindible narratividad.

En un único espacio figurativo o en varios se constituye así un contiguum, una especie de contigüidad cronificada en la que los valores plásticos se mezclan indiscerniblemente con los narrativos. Formas y figuras devienen escenario y personajes. El espacio de la representación es consumido como tiempo para la sucesión 0 , en último término y por ilusión representativa, como suceso. El cuadro esta ahí, extensión admirable pero también intención interpretable, para disfrute de nuestros ojos y evocación de nuestras referencias culturales. Porque la plástica es geometría pero también historia, deslumbramiento de las formas pero también reconocimiento del hecho.

Una vez asumida la amplia familia en la que se integra y a la espera de la genética que permita establecer vínculos y grados de parentesco entre las distintas -aunque en el fondo fraternales- manifestaciones de la narración figurativa, habrá que estudiar la historieta a partir de los antecedentes existentes y con las mencionadas limitaciones cronológicas y conceptuales. También con la esperanza del creciente interés por esta forma de expresión y las prometedoras investigaciones en curso. En los últimos años se han multiplicado las publicaciones teóricas, las tesis doctorales y los cursos o talleres especializados. Son, 
en general, iniciativas individuales, algunas provisionalmente agrupadas, pero sin muchas conexiones conceptuales $y$, desde luego, sin ningún horizonte teórico de convergencia. Tres áreas suelen repartirse el objeto de estudio desde perspectivas en origen distintas pero, al final, con evidentes paralelismos. En las facultades de bellas artes se suele abordar la historieta desde una perspectiva estética, en las de ciencias de la comunicación desde una perspectiva mediática y en las de letras desde una perspectiva semiótico-narratológica. Pero empiezan a ser frecuentes los acercamientos socio-históricos, psicológicos, de género... La investigación sobre historieta aumenta y se diversifica, todavía insuficientemente conectada, sin constituir equipos de trabajo o grupos de investigación, en algunos casos sin ser conscientes de los nexos conceptuales que las agrupa 0 del ámbito global en el que se integran. Pero los progresos son rápidos.

El estudio de la historieta en España, por iniciativas individuales 0 de grupos con gran motivación, ha alcanzado estándares homologables a los de países pioneros en este campo como Francia, Italia, Argentina o Estados Unidos. Impulsada por un patrimonio rico y original, inició desde finales de los años sesenta una tarea de reivindicación, análisis y catalogación que todavía está lejos de haber culminado. Pero ha contribuido no solo a mantener vivo el pasado sino también a impulsar el futuro. Adolece, como en otros lugares, de comunicación interna, de reconocimiento de las referencias ajenas o de consenso teórico suficiente. Lo cual condena a la fluctuación de datos, a la repetición de argumentos y al enquistamiento de algunos debates. Pero en los últimos años y con la ayuda de las nuevas tecnologías una nueva generación de críticos y divulgadores hace pensar en estimulantes progresos.

El presente número de Arbor se integra, al tiempo que da cuenta, en este panorama. Responde al nuevo interés que la historieta está despertando y al descubrimiento ya no de sus cantidades sino de sus calidades. El hecho mismo de que la revista del CSIC se haga eco por primera vez de esta forma de expresión constituye un síntoma más de este interés. A su vez, para quienes aquí colaboramos, la empresa supone al tiempo un reconocimiento y un desafío. Una situación muy similar a la que se produce en estos momentos en el ámbito editorial y en el creativo. El medio se crece con las expectativas que genera, expandiendo así una espiral difícil de calibrar habida cuenta de la cantidad de factores que inciden en ella, crisis incluida. Los firmantes de los diversos artículos, como la mayor parte de los agentes implicados en la actualidad de la historieta, procuran no solo estar a la altura, sino, a ser posible, llegar un poco más alto.

Las páginas que siguen han sido concebidas de manera que ofrezcan un recorrido, si no exhaustivo, muy completo de la Historia de nuestra historieta. Con importantes aportaciones, como la de la propia fecha de sus inicios, que Manuel Barrero sitúa en 1857. A partir de aquí, el lector podrá reconstruir los muy peculiares avatares de nuestras viñetas, desde los balbuceos temáticos y expresivos de finales del siglo XIX y principios del XX, la utilización propagandística durante la guerra o el papel solo relativamente moralizante durante el franquismo hasta la radicalidad de la transición, la experimentación de los años ochenta, el intimismo de la última década... Y, además del relato completo de sus peripecias durante el último siglo y medio, el número se completa con otras perspectivas imprescindibles para una buena comprensión de los mecanismos que utiliza este medio. Mecanismos formales como los que Jesús Jiménez Varea analiza en su estudio comparativo entre el tratamiento de ciertos temas y el desarrollo de los recursos expresivos que permiten contarlos. Mecanismos de alienación como los que denuncia Rosario Jiménez en su análisis de la historieta sentimental dirigida a las niñas. Arrebatos críticos como el estallido underground de los primeros setenta que describe $\mathrm{Pa}$ blo Dopico. La proyección de los autores españoles en los mercados extranjeros que expone Viviane Alary. El despertar de una conciencia femenina que Adela Cortijo pone de relieve. $Y$ otras muchas aportaciones que convierten este número en panorámica completa de la Historia de la historieta y en radiografía sintomática de la encrucijada en la que se encuentra. En ese sentido, resultan especialmente reveladores los artículos de Santiago García y de Álvaro Pons. El primero pone el foco en la más reciente producción, se moja haciendo su selección, exponiendo sus criterios y diseccionando el alcance de las tendencias y formatos más recientes. Pons, por su parte, nos ofrece algo tan esencial como insistentemente ocultado 0 insuficientemente estudiado, las cifras de nuestra industria y su evolución en los últimos años.

La historieta española está más viva que nunca. Creativa, trascendente, experimental, testimonial, satírica... Como 
siempre, pero realizada con mayor compromiso autorial $y$, sobre todo, consumida con menos prejuicios estéticos por un público abierto a nuevas formas narrativas. Así, un medio que era para muchos espacio de la nostalgia se ha convertido en fuente de innovación, seña de modernidad, lectura sorpresiva y altamente gratificante. Todo a partir de la reinversión, la exploración infinitamente actualizable, de una habilidad 0 , más bien, de una estrategia vieja como la humanidad, al menos como el arte, la de contar historias en imágenes. Las páginas que siguen dan cuenta de esta efervescencia y la explican en sus causas históricas, en su evolución temática y en sus resortes formales. El lector podría verificar todo ello yendo, simplemente, a una librería y comprando un cómic, un tebeo, una novela gráfica, un álbum de historietas... Pero, sin la lectura de este número de Arbor, no lo entendería tan bien ni lo disfrutaría tanto. En cualquier caso, lo uno no quita lo otro.

Terminado de redactar: 17 de diciembre de 2010 